\title{
Demographic Determinants of Work-Family Conflict among Female Factory Workers in South Africa
}

\author{
T. Mjoli, M. Dywili, and N. Dodd
}

\begin{abstract}
The study examines the relationship between work-family conflict and selected demographic variables among female factory workers in East London, South Africa. The independent variables for the study were selected demographic variables, while work-family conflict is the dependent variable. The demographic variables concerned are age, marital status, number of children and age of the youngest child. The measuring instruments were a self-designed questionnaire to measure the demographic variables and a questionnaire developed to measure work-family conflict (Cronbach's alpha = 0.90). A sample of 100 female factory workers who are employed by companies in East London, South Africa was used. Age, number of children and age of the youngest child were all found to be positively correlated to work-family conflict $(r=$ $0.38, p=0.001 ; r=0.31, p=0.002 ; r=0.27, p=0.01$ respectively) For marital status the findings were contrary to previous research findings, as the researcher found that marital status is not significantly positively related to work-family conflict $(\mathrm{r}=-\mathbf{0 . 0 8}, \mathrm{p}=\mathbf{0 . 4 2})$.
\end{abstract}

Index Terms-Work-family conflict, demographic variables, female factory workers.

\section{INTRODUCTION}

Workers face challenges of managing their work and family roles, and importantly, these challenges have become more numerous and complex [1]. The focus towards work-family issues and work-family practices in particular, has been driven by a number of major demographic changes. These include the increased employment of women [2], the rising number of dual-career couples and single-parent families [3], and the enlargement of the elderly population [4].

The main objective of the study is:

To examine the role of selected demographic variables in work-family conflict.

To provide results that may help to improve circumstances and professional careers of female employees in South Africa.

To provide results that may lead to a deeper understanding of the relationship between demographic variables and work-family conflict.

\section{HYPOTHESES}

Hypothesis - 1

$\mathrm{H}_{\mathrm{o}}$-Age will not be significantly positively related to the work-family conflict that a female factory worker experiences.

Manuscript received October 21, 2012; revised December 23, 2012.

The authors are with the University of Fort Hare, Eastern Cape, South Africa (e-mail: tmjoli@ufh.ac.za,mdywili@ufh.ac.za,ndodd@ufh.ac.za).
$\mathrm{H}_{1}$ - Age is significantly positively related to the work-family conflict that a female factory worker experiences.

Hypothesis -2

$\mathrm{H}_{\mathrm{o}}$ - Married female factory workers will not experience significantly more work-family conflict than single female factory workers.

$\mathrm{H}_{2}$ - Married female factory workers will experience significantly more work-family conflict than single female factory workers.

Hypothesis -3

$\mathrm{H}_{0}$ - The number of children that a female factory worker has will not be significantly positively related to the work-family conflict that she experiences.

$\mathrm{H}_{3}$ - The number of children that a female factory worker has will be significantly positively related to the work-family conflict that she experiences.

Hypothesis -4

$\mathrm{H}_{0}-$ Female factory workers a youngest child that is under six years of age will not experience more work-family conflict as compared to female factory workers with a youngest child above six years of age.

$\mathrm{H}_{4}$ - Female factory workers with a youngest child under six years of age will experience more work-family conflict as compared to female factory workers with a youngest child above six years of age.

\section{SignifiCANCE OF THE StUdY}

Workforces are becoming increasingly diverse all over the world, and it is something to be appreciated. It, however, brings about many problems in the management of human resources that must be solved. One aspect of workforce diversity is the increasing number of women that are employed in many organisations. One major problem, which working women experience is work-family conflict, which often leads to high levels of stress [4]. This study will explore this problem in an attempt to unravel some of its complexities. It is hoped that the resulting knowledge will be of assistance to managers in all organisations.

\section{AGE AND WORK-FAMILY CONFLICT}

According to many career models, individuals may view their careers differently depending on which age-related career stage they are in [5]. In particular, researchers have observed that, in early stages of their careers, individuals are often willing to sacrifice their personal lives in the interest of their career progression [6]. However, as individuals advance in age to the maturity stage of their careers, they have been found to place a greater emphasis on a balance between their 
work and family lives when assessing their careers. Thus, because of the greater priority that individuals give to their family roles as they age, the career satisfaction of older individuals is likely to be more negatively affected by work-family conflict than that of younger individuals.

\section{MARital Status AND WorK-FAMily CONFLiCT}

Prior research has found that being married leads individuals to give their personal lives priority over their work lives [7]. Similarly, being a parent increases the importance to individuals of their family roles [7]. Because of the greater priority that individuals give to their family roles once they get married and/or have children, they may be more likely to be dissatisfied when their work roles spill over into their family roles than are individuals who are not married and/or do not have children. Thus, we expect married women to show more work-family conflict than unmarried ones. We also expect the number of children that a woman has to be significantly positively associated with work-family conflict.

\section{CHILDREN AND WORK-FAMILY CONFLICT}

Research to date has established that work-family conflict increases as one's obligation to the family expands through marriage and arrival of the children [8]. It also has been argued that this conflict will diminish, or at least decrease, as the age of the youngest child increases. Parents with children under the age of six had the highest levels of work-family conflict, followed by parents of school-age children [9]. Employees with no children reported the least amount of work-family conflict. It is therefore hypothesized that parents of younger children are likely to report higher levels of work-family conflict.

\section{RESEARCH METHOD}

This research is of a non-experimental, exploratory and quantitative nature. A survey was conducted to collect the empirical data. Exploratory research is done to explore relatively unknown areas in order to gain new insight and understanding into a phenomenon. A sample of $n=100$ female factory workers was drawn in East London, in the Eastern Cape Province of South Africa.

\section{RESULTS}

\section{A. Internal Consistency of the Main Measuring Scales}

The population sample for this research study involves five organisations. A sample of 100 female factory workers who are employed by companies in East London, Eastern Cape Province was used. The sampling approach which has been used in this study is the non-probability purposive sampling method. Internal consistencies of scales used for rating questions on work-family conflict and occupational stress were sufficient and reliable with a Cronbach's alpha of 0.72 and 0.82 respectively. This confirms that these scales adequately measure the work-family conflict and occupational stress constructs. Since these scales were found to be reliable, i.e. they met the criteria of sufficient internal consistency $(>0.70)$, these scales were accepted for further data analysis.

\section{B. Results}

1) Hypothesis 1: correlation between age and work-family conflict

$\mathrm{H}_{\mathrm{o}}$-Age will not be significantly positively related to the work-family conflict that a female factory worker experiences.

$\mathrm{H}_{1}$ - Age will be significantly positively related to the work-family conflict that a female factory worker experiences.

As shown in Table One, age is significantly positively correlated with work-family conflict $(r=38, p=0.001)$.

TABLE I: PEARSON CORRELATION OF WORK-FAMILY CONFLICT AND DEMOGRAPHIC VARIABLES

\begin{tabular}{|c|c|c|c|}
\hline Variable & Age & Marital Status & $\begin{array}{l}\text { Number of } \\
\text { Children }\end{array}$ \\
\hline Work-family Conflict & 0.383 & -0.081 & 0.315 \\
\hline Assistant channel & $(0.000)^{*}$ & $(0.422)$ & $(0.002)^{*}$ \\
\hline
\end{tabular}

2) Hypothesis 2: correlation between marital status and work-family conflict

$\mathrm{H}_{\mathrm{o}}$ - Married female factory workers will not experience significantly more work-family conflict than single female factory workers.

$\mathrm{H}_{2}$ - Married female factory workers will experience significantly more work-family conflict than single female factory workers.

Table One shows that marital status is not significantly positively related to work-family conflict $(r=-0.08, p=$ $0.42)$.

3) Hypothesis 3: correlation between number of children and work-family conflict

$\mathrm{H}_{0}$ - The number of children that a female factory worker has will not be significantly positively related to the work-family conflict that she experiences.

$\mathrm{H}_{3}$ - The number of children that a female factory worker has will be significantly positively related to the work-family conflict that she experiences.

As exhibited in Table One, the number of children is significantly positively related to work-family conflict ( $r=$ $0.32, p=0.01)$.

4) Hypothesis 4: correlation between age of last-born child and work-family conflict

$\mathrm{H}_{0}-$ Female factory workers with a youngest child under six years of age will not experience more work-family conflict as compared to female factory workers with children above six years of age.

$\mathrm{H}_{4}-$ Female factory workers with the last-born child under six years of age will experience more work-family conflict as compared to female factory workers with children above six years of age.

As shown in Table One, age of youngest child is significantly positively related to work-family conflict ( $r=$ $0.27, p=0.01$ ). 


\section{Discussion AND CONCLUSION}

As shown in Table One, age is significantly positively correlated with work-family conflict $(r=38, p=0.001<$ 0.05). The research hypothesis $\left(\mathrm{H}_{1}\right)$ is accepted. These findings are in line with the previous research findings. In particular researchers have observed that in early stages of their careers, individuals are often willing to sacrifice their personal lives in the interest of their career progression [6].

Marital status is not significantly positively related to work-family conflict $(r=-0.08, p=0.42,>0.05)$. The research hypothesis $\left(\mathrm{H}_{2}\right)$ is rejected and null hypothesis $(\mathrm{H} 0)$ accepted. These findings are in contrary to previous research findings. Prior research has found that being married leads individuals to give their personal lives priority over their work lives [7].

The number of children is significantly positively related to work-family conflict $(r=0.32, p=0.01,<0.05)$. The research hypothesis $\left(\mathrm{H}_{3}\right)$ is accepted. Research to date has established that work family conflict increases as one's obligation to the family expands through the arrival of children [8].

Age of the last born child is significantly positively related to work-family conflict $(r=0.27, p=0.01,<0.05)$. The research hypothesis $\mathrm{H}_{4}$ is accepted, i.e. women with children under six years of age experience more work-family conflict as compared to women with children above six years of age. Parents with children under the age of six had the highest levels of work-family conflict, followed by parents with school-age children [9].

\section{REFERENCES}

[1] J. R. Mesmer-Magnus and C. Viswesvaran, "Convergence between measures of work-to-family and family-to-work conflict: A meta-analytic examination," Journal of Vocational Behavior, vol. 67, pp. 215-232, 2005 .

[2] F. J. Milliken, L. L. Martins, and H. Morgan, "Explaining organizational responsiveness to work-family issues: The role of human resource executives as issue interpreters," Academy of Management Journal, vol. 41, no. 5, pp. 580-592, 1998.
[3] J. D. Goodstein, "Institutional pressures and strategic responsiveness: employer involvement in work-family issues," Academy of Management Journal, vol. 37, no. 2, pp. 350-382, 1994

[4] R. Hendrickson, "What does the future hold for health care, elder care, and long-term care coverage for workers and their families?" Perspectives on Work, vol. 4, pp. 2, pp. 16-17, 2000.

[5] J. F. Viega, "Toward understanding employee reluctance to participate in family friendly programs," Human management review, vol. 14, pp 337-351, 1983.

[6] J. R. Gordon and K. S. Whelan-Berry, "The relationship among work-family conflict and enhancement, organizational culture and work outcomes for older working women," Journal of occupational health psychology, vol. 12, pp. 350-364, 2007.

[7] F. Blau, M. Ferber, and A. Winker, The economics of women, men and work, 3rd edition, Upper Saddle River, NJ: Prentice Hall, 1998.

[8] R. A. Cooke and D. M. Rousseau. "Stress and strain from family roles and work-roles," Journal of applied psychology, vol. 69, no. 2, pp. 252-60, 1984.

[9] G. L. Staines and P. O'Connor, "Conflicts among work, leisure, and family roles," Monthly labour review, vol. 103, no. 8, pp. 35-39, 1980.

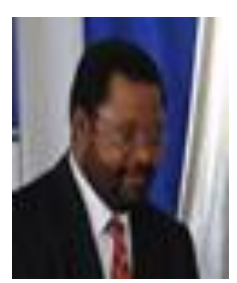

Themba Mjoli holds a PHD in Industrial and Organisational Psychology from the University of South Africa. He is currently the Executive Dean of the Faculty of Management and Commerce at the University of Fort Hare.

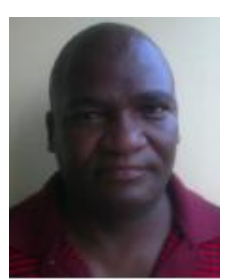

Mtutuzeli Dywili holds a Masters degree in Industria and Organisational Psychology from the University of Fort Hare. He is currently a lecturer at the University of Fort Hare

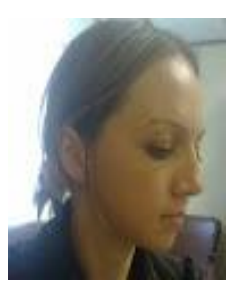

Nicole DODD received a PHD in Industrial and Organisational Psychology from Nelson Mandela Metropolitan University in 2012. She is currently a Head of Department at the University of Fort Hare. 